\title{
ANALISIS PENGARUH PROFITABILITAS TERHADAP NILAI PERUSAHAAN DENGAN CORPORATE SOCIAL RESPONSIBILITY SEBAGAI VARIABEL PEMODERASI PADA PERUSAHAAN PERTAMBANGAN DI BEI TAHUN 2010-2014
}

\author{
Farianita Lestari \\ Dewi Rahmayanti \\ Program Studi Manajemen Fakultas Ekonomi dan Bisnis Universitas Bengkulu
}

\begin{abstract}
The purpose of this research to analyze the influence of Return On Asset (ROA) and Net Profit Margin (NPM) on corporate value with CSR as a moderating variable in the mining company listed on the Indonesia Stock Exchange in the period of 2010 -2014. The number of population for this research is 40 company and the number of sample that examined after passed the purposive sampling phase is 11 company. The analysis method used in this research that is with moderated regression analysis, panel data regression, hypothesis test that is determinant coefficient, test $F$, and test $T$. From the result of simultan analysis variable Return On Asset (ROA), Net Profit Margin (NPM) and Corporate Social Responsibility (CSR) have significant influence toward corporate value (tobin's $Q$ ). The result of partial this research shows that only Return On Asset (ROA) have significant influence toward corporate value (tobin's Q). The disclosure of Corporate Social Responsibility (CSR) is can't able to moderate relation of NPM and corporate value, and able to moderate relation of ROA and corporate value.
\end{abstract}

Keywords: Tobin's Q, Return On Aset (ROA), Net Profit Margin (NPM) and Corporate social responsibility (CSR)

\section{PENDAHULUAN}

\section{Latar Belakang}

Perusahaan didirikan pada umumnya memiliki tujuan tertentu yang ingin dicapai dalam usaha untuk memenuhi kepentingan dan kesejahteraan pemilik perusahaan atau para pemilik saham (stockholders). Di era globalisasi seperti sekarang ini, persaingan antar perusahaan tentunya semakin ketat, perusahaan akan berlombalomba untuk meningkatkan daya saing di berbagai sektor untuk dapat menarik minat investor untuk berinvestasi. Salah satu faktor yang biasanya menjadi bahan pertimbangan oleh investor adalah nilai perusahaan. Secara umum, naik turunnya nilai perusahaan dipengaruhi oleh faktor keuangan (Mulianti, 2010). Faktor keuangan yang sangat berperan penting dalam peningkatan nilai perusahaan yaitu kinerja keuangan. Penilaian kinerja keuangan merupakan salah satu cara yang dapat dilakukan oleh pihak perusahaan agar dapat memenuhi kewajibannya terhadap para penyandang dana dan juga untuk mencapai tujuan yang telah ditetapkan oleh perusahaan. Kinerja keuangan dapat ditunjukkan melalui hasilhasil perhitungan dari laporan keuangan. Salah satu alat ukur utama untuk 
mengevaluasi kinerja keuangan perusahaan dalam kegiatan investasi yang biasanya digunakan oleh para investor adalah rasio profitabilitas. Rasio profitabilitas menunjukkan hasil pengelolaaan manajemen perusahaan atas dana yang diinvestasikan. Menurut Mardiyanto (2009: 196), Return on assets (ROA) merupakan salah satu rasio profitabilitas yang dapat mengukur kemampuan perusahaan dalam menghasilkan laba dari aktiva yang digunakan. Menurut Bastian dan Suhardjono (2006: 299).

Net Profit Margin adalah perbandingan antara laba bersih dengan penjualan. Penulis menggunakan rasio ROA dan NPM sebagai indikator profitabilitas dalam mengukur nilai perusahaan. Beberapa penelitian telah dilakukan untuk mengetahui pengaruh profitabilitas terhadap nilai perusahaan. Penelitian Munawaroh dan Priyadi (2014) menyatakan bahwa ROA menunjukkan pengaruh negatif terhadap nilai perusahaan. Hasil penelitian variabel NPM justru menunjukkan pengaruh yang signifikan terhadap nilai perusahaan. Penelitian Triagustina, dkk (2012) menemukan bahwa secara simultan Return on Assets berpengaruh signifikan terhadap nilai perusahaan. Namun, secara parsial Return on Assets tidak berpengaruh signifikan terhadap nilai perusahaan. Dengan adanya perbedaan hasil penelitian tersebut menunjukkan adanya variabel lain yang turut mempengaruhi hubungan kedua rasio tersebut terhadap nilai perusahaan. Menurut penelitian Susanto dan Subekti (2012) ada faktor non keuangan yang keberadaannya juga dapat mempengaruhi hubungan antara faktor keuangan dengan nilai perusahaan (Pemoderasi), salah satu nya yaitu corporate social responsibility. Istilah Corporate Social Responsibility (CSR) erat kaitannya dengan masyarakat dan perusahaan-perusahaan besar. Pada dasarnya CSR merupakan bentuk kontribusi perusahaan untuk keberlangsungan kehidupan masyarakat di sekitarnya, baik secara sosial, ekonomi dan lingkungan masyarakat.

Indonesia merupakan salah satu negara dengan kekayaan sumber daya alam yang melimpah, salah satunya adalah bahan tambang. Industri pertambangan merupakan salah satu sektor industri yang punya sumbangsih besar bagi Indonesia untuk memenuhi kebutuhan bahan baku industri dalam negeri, memenuhi kebutuhan energi, menghasilkan devisa bagi pembangunan, menyediakan lapangan kerja dan menciptakan kesempatan usaha bagi lingkungan sekitarnya.

Perusahaan pertambangan dipilih karena kegiatan bisnisnya yang bersentuhan langung dengan pemanfaatan sumber daya alam yang mana berdampak langsung pada lingkungan. Jaringan Advokasi Tambang (Jatam) memperkirakan, sekitar 70 $\%$ kerusakan lingkungan Indonesia disebabkan oleh operasi pertambangan. Sekitar 3,97 juta hektare kawasan lindung terancam pertambangan dan Sekitar 4.000 DAS di Indonesia, 108 rusak parah. Persoalan lingkungan dengan pencemaran limbah misalnya, PT Lapindo Brantas di Sidoarjo dengan lumpur yang tiada henti-hentinya mengakibatkan kerusakan lingkungan dan menelantarkan ribuan masyarakat yang masalahnya juga belum terselesaikan sampai hari ini. Dalam hal ini setidaknya ada yang dilanggar yakni pelanggaran 
aspek lingkungan karena melakukan kerusakan lingkungan dan aspek kemanusiaan karena menelantarkan ribuan masyarakat yang menjadi korban.

Puspaningrum (2014) menemukan bahwa pada kurun waktu 2006 hingga 2011 terdapat 30 perusahaan pertambangan yang terdaftar di BEI. Dari 30 perusahaan tersebut, hanya 7 perusahaan yang telah menjalankan program CSR dan menyusun Sustainbility Report, sedangkan menurut aktivis dari Lingkar Studi CSR pada tahun 2012 hanya sekitar 10 perusahaan. Perusahaan pertambangan yang terdaftar di bei pada saat ini berjumlah 40 perusahaan dan yang telah menjadi anggota lebih dari 5 tahun berjumlah 32 perusahaan sedangkan $20 \%$ dari jumlah tersebut baru menjadi anggota di bawah 5 tahun. Dari 32 perusahaan yang telah menjadi anggota di BEI, 11 perusahaan diantaranya mengungkapkan kegiatan sosial perusahaan di laporan keuangan tahunan perusahaan secara konsisten. Berdasarkan uraian mengenai latar belakang masalah di atas, maka dapat diketahui permasalahan dalam penelitian ini adalah karena adanya perbedaan dari berbagai penelitian mengenai hasil pengaruh profitabilitas terhadap nilai perusahaan dan masih kurangnya pengungkapan CSR yang dilakukan oleh perusahaan-perusahaan pertambangan. Maka kemudian peneliti mengembangkan penelitian tersebut dan menggunakan variabel pengungkapan Corporate Social Responsibility sebagai variabel pemoderasi, karena diduga variabel tersebut turut serta mempengaruhi hubungan antara profitabilitas terhadap nilai perusahaan. Untuk itu beberapa rumusan masalah yang dapat penulis ambil adalah :

1. Bagaimana variabel ROA, NPM dan CSR secara bersama-sama mempengaruhi nilai perusahaan pertambangan yang terdaftar di BEI periode 2010-2014?

2. Apakah ROA berpengaruh terhadap nilai perusahaan Pertambangan di BEI periode 2010-2014?

3. Apakah NPM berpengaruh terhadap nilai perusahaan Pertambangan di BEI periode 2010-2014 ?

4. Apakah pengungkapan corporate social responsibility berpengaruh terhadap nilai perusahaan Pertambangan di BEI periode 2010-2014 ?

5. Apakah pengungkapan corporate social responsibility dapat memoderasi hubungan ROA terhadap nilai perusahaan Pertambangan di BEI periode 2010-2014?

6. Apakah pengungkapan corporate social responsibility dapat memoderasi hubungan NPM terhadap nilai perusahaan Pertambangan di BEI periode 2010-2014? 


\section{TINJAUAN PUSTAKA}

\section{Profitabilitas}

Menurut Kasmir (2008) profitabilitas merupakan rasio untuk menilai kemampuan perusahaan dalam mencari keuntungan. Penelitian ini menggunakan rasio profitabilitas karena profitabilitas adalah rasio-rasio yang menunjukan hasil akhir dari sejumlah kebijakan dan keputusan-keputusan perusahaan (Riyanto, 1995). Rasio ini digunakan untuk mengetahui kemampuan perusahaan dalam menghasilkan laba atau seberapa efektif pengelolaan perusahaan oleh manajemen. Untuk dapat melangsungkan hidupnya, perusahaan harus berada dalam keadaan yang menguntungkan. Apabila perusahaan berada dalam kondisi yang tidak menguntungkan, maka akan sulit bagi perusahaan untuk memperoleh pinjaman dari kreditor maupun investasi dari pihak luar.

Profitabilitas merupakan indikator yang paling tepat untuk mengukur kinerja keuangan perusahaan. Pada penelitian ini ukuran profitabilitas yang digunakan adalah Return on Asset (ROA) dan Net Profit Margin (NPM) yang merupakan cerminan kemampuan perusahaan dalam mengolah aset dan juga modal dalam memperoleh laba.

a. Return on Assets

Kasmir (2008 : 199) menyatakan bahwa rasio ini adalah rasio keuntungan bersih setelah pajak terhadap jumlah asset secara keseluruhan. Rasio ini merupakan suatu ukuran untuk menilai seberapa besar tingkat pengembalian dari asset yang dimiliki. Apabila rasio ini tinggi berarti menunjukkan adanya efisiensi yang dilakukan oleh pihak manajemen. Penelitian dengan menggunakan rasio penghitungan ROA sudah banyak dilakukan, salah satunya seperti penelitian yang dilakukan Muliani, dkk (2014), penelitian ini menyatakan bahwa kinerja keuangan yang diproksikan dengan ROA berpengaruh signifikan terhadap nilai perusahaan. Hal ini berarti profitabilitas perusahaan dapat meningkatkan nilai perusahaan. Dengan tingkat profitabilitas yang tinggi, berarti perusahaan melakukan kegiatan operasional dengan baik, sehingga dengan tingkat operasional yang baik akan diharapkan perusahaan mampu memperoleh laba yang tinggi juga.

Menurut Wijaya dan Linawati (2014) untuk mengukur profitabilitas digunakan berupa rumus sebagai berikut :

\section{ROA $=\underline{\text { Laba Bersih }}$ Total Aktiva \\ b. Net Profit Margin}

Menurut Bastian dan Suhardjono (2006), Net Profit Margin adalah perbandingan antara laba bersih dengan penjualan. Rasio ini menunjukkan berapa besar persentase laba bersih yang diperoleh dari setiap penjualan. Semakin besar rasio ini, maka dianggap semakin baik kemampuan perusahaan untuk mendapatkan laba yang tinggi. Penelitian dengan menggunakan rasio penghitungan NPM sudah banyak dilakukan, salah satunya seperti penelitian yang dilakukan oleh Anita (2015) penelitian ini menemukan bahwa kinerja keuangan yang diproksikan dengan NPM berpengaruh positif terhadap nilai perusahaan. Hal ini menunjukan 
bahwa Semakin besar NPM, maka kinerja perusahaan diharapkan akan semakin produktif, sehingga akan meningkatkan kepercayaan investor untuk menanamkan modalnya pada perusahaan tersebut.

Menurut Munawaroh dan Priyadi (2014) untuk mengukur profitabilitas digunakan berupa rumus sebagai berikut :

$\mathrm{NPM}=\underline{\text { Laba bersih }}$

Penjualan

\section{Nilai Perusahaan}

Nilai perusahaan menurut Rika dan Islahudin (2008: 7) didefinisikan sebagai nilai pasar. Nilai perusahaan dapat memberikan kemakmuran pemegang saham secara maksimum apabila harga saham perusahaan meningkat. Nilai pasar perusahaan dapat diukur dengan Tobin's Q. Tobin's $Q$ atau yang dikenal juga sebagai Q ratio mengukur kesempatan berkembang suatu perusahaan dengan membandingkan market value dari aset perusahaan dengan replacement value dari aset perusahaan. Tobin's Q merupakan rasio market value aset perusahaan (diukur dengan market value dari saham yang beredar dan hutang perusahaan) terhadap replacement cost asset perusahaan (Tobin, 1969). Menurut Hadianto (2013) nilai perusahan diukur dengan Tobin's Q dengan rumus sebagai berikut :

Tobin's Q = Closing Price x Jumlah Saham Beredar + Liabilitas

\section{Teori Stakeholder}

Total Aset

Januarti dan Apriyanti (2005) mengemukakan bahwa teori stakeholder mengasumsikan bahwa eksistensi perusahaan memerlukan dukungan stakeholder sehingga aktivitas perusahaan juga mempertimbangkan persetujuan dari stakeholder. Ghozali dan Chariri (2007) menjelaskan bahwa stakeholders theory mengatakan bahwa perusahaan bukanlah entitas yang hanya beroperasi untuk kepentingannya sendiri namun harus memberikan manfaat bagi stakeholder-nya (pemegang saham, kreditor, konsumen, supplier, pemerintah, masyarakat, analis, dan pihak lain).

\section{Corporate Social Responsibility (CSR)}

CSR atau tanggung jawab sosial perusahaan didefinisikan sebagai komitmen bisnis untuk memberikan kontribusi bagi pembangunan ekonomi yang dapat bekerja dengan karyawan dan perwakilan mereka, masyarakat sekitar dan masyarakat yang lebih luas untuk memperbaiki kualitas hidup, dengan cara yang baik bagi bisnis maupun pengembangan secara berkelanjutan. Pengungkapan sosial yang dilakukan oleh perusahaan umumnya bersifat voluntary (sukarela), unaudit (belum diaudit), dan unregulated (tidak dipengaruhi oleh peraturan tertentu) dengan pelaporan sosial perusahaan berdasarkan standar GRI (Global Reporting Initiative). Konsep pelaporan CSR digagas dalam Global Reporting Inisiative (GRI). Dalam GRI Guidelines disebutkan bahwa perusahaan harus menjelaskan dampak aktivitas perusahaan terhadap ekonomi, lingkungan dan sosial pada bagian standard disclosures. Tiga dimensi tersebut kemudian diperluas menjadi enam pengungkapan, yaitu ekonomi, sosial, lingkungan, 
praktek tenaga kerja, hak asasi manusia, masyarakat, dan tanggung jawab produk, dimana didalamnya terdapat penjelasan sejumlah tujuh puluh sembilan (79) item. Perhitungan CSDI dilakukan dengan menggunakan pendekatan dikotomi, yaitu setiap item CSR dalam instrumen diberi skor 1 jika diungkapkan dan nilai 0 jika tidak diungkapkan Danu (2011). Selanjutnya skor dari setiap item dijumlahkan untuk memperoleh skor keseluruhan dari seluruh perusahaan.

CSR diukur dengan menggunakan standar GRI (Global Reporting Initiatives), yaitu sebagai berikut :

$$
\mathrm{CSDI}_{\mathrm{J}}=\frac{\mathrm{n}}{\mathrm{k}}
$$

Sumber: Danu (2011)

di mana:

CSDIj =pengungkapan Corporate Social Responsibility Index pada perusahaan j

$\mathrm{n} \quad=$ jumlah skor pengungkapan yang diperoleh untuk perusahaan $\mathrm{j}$

$\mathrm{k} \quad=$ jumlah skor maksimal (79)

\section{Kerangka Analisis}

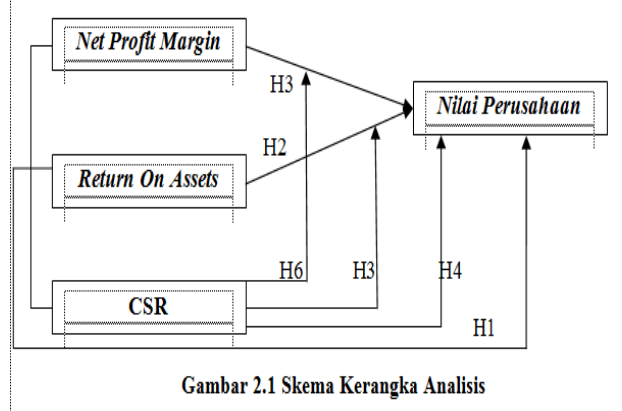

Keterangan :

Variabel Independen: ROA dan NPM

Variabel Dependen : Tobins Q

Variabel Moderasi : CSR

\section{Perumusan Hipotesis}

Maka adapun hipotesis dari penelitian ini, yaitu :

H1= ROA, NPM dan CSR secara bersama-sama mempengaruhi nilai perusahaan.

$\mathrm{H} 2=\mathrm{ROA}$ berpengaruh terhadap nilai perusahaan.

H3 = NPM berpengaruh terhadap nilai perusahaan.

$\mathrm{H} 4=$ Pengungkapan corporate social responsibility berpengaruh terhadap nilai Perusahaan.

H5=Pengungkapan corporate social responsibility dapat memoderasi hubungan ROA terhadap nilai perusahaan.

H6=Pengungkapan corporate social responsibility dapat memoderasi hubungan NPM terhadap nilai perusahaan.

METODE PENELITIAN 
Jenis penelitian ini merupakan penelitian kuantitatif yaitu metode penelitian yang berlandaskan pada filsafat positivism, digunakan untuk meneliti pada populasi atau sampel tertentu, pengumpulan data menggunakan instrument penelitian, analisis data bersifat kuantitatif atau statistik, dengan tujuan untuk menguji hipotesis yang telah ditetapkan (Sugiyono 2012:11).Populasi dalam penelitian ini adalah seluruh perusahaan pertambangan yang terdaftar di BEI. Periode analisis dalam penelitian ini yaitu dari 2010 sampai 2014. Pemilihan sampel dilakukan dengan menggunakan metode purposive sampling dengan tujuan untuk mendapatkan sampel yang representative sesuai dengan kriteria yang di tentukan. Adapun kriteria sampel yang akan digunakan yaitu:

a. Perusahaan yang merupakan industri pertambangan yang terdaftar di Bursa Efek Indonesia periode 2010-2014.

b. Perusahaan yang melakukan pengungkapan CSR setiap tahun.

c. Perusahaan mengungkapkan data yang dibutuhkan dalam penelitian secara lengkap setiap tahun selama periode 2010-2014.

Berdasarkan kriteria yang telah ditetapkan sebelumnya, maka perusahaan yang menjadi sampel dalam penelitian ini adalah 11 perusahaan. Data yang digunakan dalam penelitian ini adalah data sekunder. Data sekunder dalam penelitian ini diperoleh dari artikel, jurnal, dan laporan keuangan tahun sebelumnya (20102014) yang didapat dimasing-masing perusahaan-perusahaan tambang yang terdaftar di BEI.

Teknik pengumpulan data yang digunakan dalam penelitian ini adalah dokumentasi yang berhubungan dengan indikator-indikator atau variabel-variabel yang digunakan dalam penelitian. Untuk data pengukuran kinerja CSR menggunakan pendekatan dikotomi yang merupakan suatu cara pemberian skor pada pengukuran sosial laporan tahunan yang dilakukan dengan pengamatan mengenai ada tidaknya suatu item informasi yang ditentukan dalam laporan tahunan, apabila item informasi tidak ada dalam laporan tahunan maka diberi skor 0 , dan jika item informasi yang ditentukan ada dalam laporan tahunan maka diberi skor 1 . Teknik analisis yang akan digunakan dalam penelitian ini adalah dengan menggunakan analisis statistik regresi data panel, uji t dan uji f.

\section{HASIL PENELITIAN}

\section{Uji Regresi Data Panel}

Penentuan model terbaik regresi data panel antara common effect, fixed effect, dan random effect menggunakan dua teknik estimasi model. Dua teknik ini digunakan dalam regresi data panel untuk memperoleh model yang tepat dalam mengestimasi regresi data panel. Dua uji yang digunakan, pertama Chow test digunakan untuk memilih antara model common effect atau fixed effect. Kedua, Hausman test digunakan untuk memilih antara model fixed effect atau random effect yang terbaik dalam mengestimasi regresi data panel. 
Berdasarkan Chow Test dengan menggunakan Eviews 7.0, diperoleh nilai probabilitas sebesar 0.0003 . Hal ini menunjukan bahwa Chow Test signifikan (lebih kecil dari 5\%) maka $\mathrm{H}_{1}$ diterima, artinya model fixed effect dapat digunakan. Selanjutnya, Hausman Test dilakukan untuk menentukan pemilihan model terbaik antara fixed effect dan random effect. Berdasarkan Hausman Test, diperoleh nilai probabilitas sebesar 0.3307. Hal ini menunjukan bahwa Hausman Test lebih besar dari $5 \%$ maka $\mathrm{H}_{0}$ diterima, artinya model Random effect yang digunakan.

\section{Uji Simultan (Uji F)}

Uji $\mathrm{F}$ hitung menunjukkan apakah semua variabel independen yang dimasukkan dalam model mempunyai pengaruh secara bersama-sama terhadap variabel dependennya. Uji $\mathrm{F}$ dalam penelitian ini adalah untuk mengetahui pengaruh antara ROA, NPM,CSR, dan interaksi antara ROA*CSR, maupun NPM*CSR terhadap nilai perusahaan secara simultan.

Hipotesis 1:

$\mathrm{H}_{\mathrm{a}}=\mathrm{ROA}, \mathrm{NPM}, \mathrm{CSR}, \mathrm{ROA} * \mathrm{CSR}, \mathrm{NPM} * \mathrm{CSR}$ secara simultan berpengaruh terhadap nilai perusahaan.

$\mathrm{H}_{0}=\mathrm{ROA}, \mathrm{NPM}, \mathrm{CSR}, \mathrm{ROA} * \mathrm{CSR}, \mathrm{NPM} * \mathrm{CSR}$ secara simultan tidak berpengaruh terhadap nilai perusahaan.

Tabel 1

Signifikansi Uji F

\begin{tabular}{|l|l|}
\hline & Prob (F stat) \\
\hline $\begin{array}{l}\text { Model } \\
\text { Persamaan }\end{array}$ & 0.019205 \\
\hline
\end{tabular}

Sumber : Hasil Olahan Penulis menggunakan Eviews 7.0, 2016

Seperti terlihat pada Tabel di atas didapat probabilitas F statistik sebesar 0.019205 dengan tingkat signifikansi 5\%. Oleh karena itu probabilitas lebih kecil dari 0,05 , maka Ha diterima yang artinya ada pengaruh yang signifikan antara variabel ROA,NPM,CSR, dan variabel moderasi terhadap nilai perusahaan pertambangan secara simultan.

\section{Analisis Koefisien determinasi berganda $\left(\mathbf{R}^{2}\right)$}

Koefisien determinasi merupakan ikhtisar yang menyatakan seberapa baik garis regresi mencocokkan data. Nilai $\mathrm{R}^{2}$ berkisar antara 0-1. Nilai yang kecil berarti kemampuan variabel independen dalam menjelaskan variasi variabel dependen amat terbatas. Sebaliknya, nilai yang mendekati satu berarti variabelvariabel independen memberikan hampir semua informasi yang dibutuhkan untuk memprediksi variasi variabel dependen.

Tabel 2 
Nilai Adj R-Square Pada Model Persamaan

\begin{tabular}{|c|c|}
\hline & Nilai Adj R-Square \\
\hline Model Persamaan & 0.424149 \\
\hline
\end{tabular}

Berdasarkan Tabel di atas terlihat besarnya angka $\mathrm{R}^{2}$ sebesar 0.424149 atau $42,41 \%$. Artinya, variasi nilai perusahaan (variabel dependen) bisa dijelaskan oleh variabel bebas sebesar 42,41 \%. Sedangkan sisanya sebesar 57,59\% dijelaskan oleh faktor- faktor lainya di luar variabel independen yang di gunakan di dalam penelitian.

\section{Uji Parsial (Uji t)}

Berdasarkan hasil uji regresi, dengan demikian, persamaan penelitian dapat diuraikan sebagai berikut :

$\mathrm{Y}=1.420734+6.377327 \mathrm{ROA}-2.179689 \mathrm{NPM}+0.554479 \mathrm{CSR}+6.442836$ ROA.CSR $-2.315111 \mathrm{NPM} . \mathrm{CSR}+\mathrm{e}$

Dari hasil analisis regresi tersebut dapat dijelaskan bahwa nilai perusahaan tahun 2010-2014 pada perusahaan pertambangan di BEI konstan sebesar 1.420734 apabila semua nilai variabel bebas dianggap nol.

a. Pengaruh Return On Aset terhadap nilai perusahaan . Hipotesis:

$\mathrm{Ha}=$ Return On Aset memiliki pengaruh signifikan terhadap nilai perusahaan

Berdasarkan Tabel 3, variabel Return on Aset memiliki nilai koefisien sebesar 6.377327. Nilai koefisien regresi positif menunjukkan bahwa Return on Aset berpengaruh positif terhadap nilai perusahaan. Hal ini menggambarkan bahwa jika setiap kenaikan satu persen variabel Return on Aset, dengan asumsi variabel lain tetap maka akan menaikkan nilai perusahaan sebesar 6.377327. Berdasarkan dari hasil uji statistik t pada Tabel 3 dapat diketahui bahwa variabel Return on Aset menunjukkan nilai probabilitas signifikansi sebesar 0.0000. Tingkat signifikansi tersebut lebih kecil dari taraf signifikansi $\alpha=0,05$. Hal ini menunjukkan bahwa Return on Aset sebagai indikator profitabilitas berpengaruh signifikan terhadap nilai perusahaan. Dengan demikian dapat dinyatakan $\mathrm{Ha}$ diterima dan Ho ditolak.

b. Uji pengaruh Net Profit Margin terhadap nilai perusahaan .

Hipotesis:

$\mathrm{Ha}=$ Net Profit Margin memiliki pengaruh signifikan terhadap nilai perusahaan

Berdasarkan Tabel 3, variabel Net Profit Margin memiliki nilai koefisien sebesar (-2.179689). Nilai koefisien regresi negatif menunjukkan bahwa Net Profit Margin berpengaruh negatif terhadap nilai perusahaan. Hal ini menggambarkan bahwa jika setiap kenaikan satu persen variabel Net Profit Margin, dengan asumsi variabel lain tetap maka akan menurunkan nilai perusahaan sebesar 2.179689. Berdasarkan dari hasil uji statistik t pada Tabel 3 dapat diketahui bahwa variabel Net Profit Margin menunjukkan nilai probabilitas signifikansi sebesar 0.1557. Tingkat signifikansi tersebut lebih besar dari taraf signifikansi $\alpha=0,05$. Hal ini menunjukkan bahwa Net Profit Margin sebagai 
indikator profitabilitas tidak berpengaruh signifikan terhadap nilai perusahaan. Dengan demikian dapat dinyatakan Ha ditolak dan Ho diterima.

c. Uji pengaruh pengungkapan CSR terhadap nilai perusahaan . Hipotesis:

$\mathrm{Ha}=$ Corporate social Responsibility memiliki pengaruh signifikan terhadap nilai perusahaan

Berdasarkan Tabel 3, variabel Corporate social Responsibility memiliki nilai koefisien sebesar 0.554479. Nilai koefisien regresi positif menunjukkan bahwa Corporate social Responsibility berpengaruh positif terhadap nilai perusahaan. Hal ini menggambarkan bahwa jika setiap kenaikan satu persen variabel Corporate social Responsibility, dengan asumsi variabel lain tetap maka akan menaikkan nilai perusahaan sebesar 0.554479. Namun, berdasarkan dari hasil uji statistik t pada Tabel 3 dapat diketahui bahwa variabel Corporate social Responsibility menunjukkan nilai probabilitas signifikansi sebesar 0.2747. Tingkat signifikansi tersebut lebih besar dari taraf signifikansi $\alpha=0,05$. Hal ini menunjukkan bahwa Corporate social Responsibility sebagai indikator profitabilitas tidak berpengaruh signifikan terhadap nilai perusahaan. Dengan demikian dapat dinyatakan Ha ditolak dan Ho diterima.

d. Uji pengaruh pengungkapan CSR mampu memoderasi hubungan antara ROA terhadap nilai perusahaan

Hipotesis:

Ha : CSR mampu memoderasi pengaruh ROA terhadap nilai perusahaan.

Berdasarkan Tabel 3, variabel interaksi ROACSR memiliki nilai koefisien sebesar 6.442836. Nilai koefisien regresi positif menunjukkan bahwa ROACSR berpengaruh positif terhadap nilai perusahaan. Hal ini menggambarkan bahwa jika setiap kenaikan satu persen variabel ROACSR, dengan asumsi variabel lain tetap maka akan menaikkan nilai perusahaan sebesar 6.442836. Berdasarkan dari hasil uji statistik t pada Tabel 3 dapat diketahui bahwa variabel ROACSR menunjukkan nilai probabilitas signifikansi sebesar 0.0001. Tingkat signifikansi tersebut lebih kecil dari taraf signifikansi $\alpha=0,05$. Hal ini menunjukkan bahwa ROACSR sebagai indikator profitabilitas berpengaruh signifikan terhadap nilai perusahaan. Dengan demikian dapat dinyatakan Ha diterima dan Ho ditolak.

e. Uji pengaruh pengungkapan CSR dalam memoderasi hubungan antara NPM terhadap nilai perusahaan

Hipotesis:

Ha : CSR mampu memoderasi pengaruh NPM terhadap nilai perusahaan.

Berdasarkan Tabel 3, variabel interaksi NPMCSR memiliki nilai koefisien sebesar (-2.315111). Nilai koefisien regresi negatif menunjukkan bahwa NPMCSR berpengaruh negatif terhadap nilai perusahaan. Hal ini menggambarkan bahwa jika setiap kenaikan satu persen variabel NPMCSR, dengan asumsi variabel lain tetap maka akan menurunkan nilai perusahaan sebesar 2.315111. Berdasarkan dari hasil uji statistik t pada Tabel 3 dapat diketahui bahwa variabel NPMCSR menunjukkan nilai probabilitas signifikansi sebesar 0.1541. Tingkat signifikansi tersebut lebih besar dari taraf signifikansi $\alpha=0,05$. Hal ini menunjukkan bahwa NPMCSR sebagai indikator profitabilitas tidak berpengaruh 
signifikan terhadap nilai perusahaan. Dengan demikian dapat dinyatakan $\mathrm{Ha}$ ditolak dan Ho diterima.

Tabel 3

Hasil Regresi Data Panel

\begin{tabular}{|c|c|c|c|c|c|c|c|c|}
\hline Variabel & Koefisien & $\begin{array}{c}\text { Std. } \\
\text { Error }\end{array}$ & t.Statistic & Prob. & R-Squared & $\begin{array}{c}\text { Adj R. } \\
\text { Squared }\end{array}$ & $\begin{array}{c}\text { S.E of } \\
\text { regresssion }\end{array}$ & $\begin{array}{c}\text { Prob (F } \\
\text { stat) }\end{array}$ \\
\hline$\beta_{0}$ & 1.420734 & 0.547804 & 2.593509 & 0.0133 & 0.584108 & 0.424149 & 0.510827 & 0.019205 \\
\hline ROA & 6.377327 & 1.407778 & 4.530065 & 0.0000 & & & & \\
\hline NPM & -2.179689 & 1.512716 & -1.440911 & 0.1557 & & & & \\
\hline CSR & 0.554479 & 0.502137 & 1.104239 & 0.2747 & & & & \\
\hline ROA.CSR & 6.442836 & 1.528081 & 4.216293 & 0.0001 & & & & \\
\hline NPMCCSR & -2.3151111 & 1.595285 & -1.451221 & 0.1541 & & & & \\
\hline
\end{tabular}

iumber : Hasil Olahan Penulis menggunakan Eviews 7.0, 2016

\section{KESIMPULAN DAN SARAN}

\section{Kesimpulan}

Berdasarkan hasil pengujian hipotesis yang telah dilakukan terhadap hipotesis yang telah dirumuskan maka dapat ditarik kesimpulan sebagai berikut:

1. ROA,NPM, CSR dan interaksi ROA dengan CSR, ataupun NPM dengan CSR secara bersama-sama (simultan) berpengaruh yang signifikan terhadap nilai perusahaan

2. ROA berpengaruh signifikan terhadap nilai perusahaan yang artinya bahwa jumlah return dari aset menarik bagi investor dikarenakan tingkat pengembalian atas aset pada perusahaan pertambangan menunjukan kemampuan perusahaan dalam mengelolah seluruh aset yang dimiliki oleh perusahaan untuk menghasilkan laba.

3. Net Profit Margin tidak berpengaruh signifikan terhadap nilai perusahaan, dengan hasil ini menunjukan bahwa kemampuan perusahaan dalam menunjukkan tingkat presentase laba bersih dari penjualan pada perusahaan pertambangan tidak cukup menarik investor dalam hubungannya terhadap nilai perusahaan.

4. Corporate Social Responsibility tidak berpengaruh signifikan terhadap nilai perusahaan, hal ini disebabkan oleh anggapan para investor bahwa mengungkapkan kinerja sosial suatu perusahaan tidak cukup untuk menjadi indikator naiknya nilai suatu perusahaan.

5. Corporate Social Responsibility mampu memoderasi hubungan antara ROA terhadap nilai perusahaan, yang artinya investor lebih tertarik dengan adanya pengungkapan CSR di perusahaan pertambangan karena menunjukan bahwa perusahaan akan menjaga eksistensi dan hubungan baik 
antara perusahaan dan stakeholder yang mencerminkan keberlangsungan kegiatan perusahaan pertambangan di masa yang akan datang.

6. Corporate Social Responsibility tidak mampu memoderasi hubungan antara NPM terhadap nilai perusahaan, dengan perusahaan melakukan pengungkapan NPM dan CSR tidak akan mampu mempengaruhi keputusan investor dalam berinvestasi.

\section{Saran}

Berdasarkan hasil penelitian di atas implikasi yang dapat diajukan dalam penelitian ini adalah :

1. Bagi investor dapat menjadikan laporan keuangan tahunan perusahaan sebagai pedoman dengan melihat indikator ROA sebagai informasi yang dapat dijadikan pertimbangan dalam menanamkan modalnya pada perusahaan pertambangan karena terbukti bahwa ROA berpengaruh positif terhadap nilai perusahaan pertambangan.

2. Untuk perusahaan pertambangan untuk dapat meningkatkan kinerja keuangan maupun kinerja sosial dengan menampilkan kinerja keuangan maupun kinerja sosial yang baik dan transparan.

3. Bagi peneliti selanjutnya yang akan melanjutkan kajian yang sama diharapkan dapat menggunakan variabel yang selalu tersedia setiap tahunnya, agar dapat dimudahkan dalam pencarian sampel sesuai dengan kriteria sampel yang telah ditentukan, dan menggunakan periode penelitian yang lebih panjang dari penelitian ini sehingga data yang didapatkan lebih relevan.

\section{DAFTAR PUSTAKA}

Aisyatul Munawaroh, Maswar Patuh Priyadi. 2014. Pengaruh profitabilitas terhadap nilai perusahaan dengan Corporate Social Responsibility sebagai variabel moderating, Jurnal Ilmu \& Riset Akuntansi Vol. 3 No. 4, STIESIA Surabaya

Anita Batubara. 2015. Pengaruh NPM terhadap nilai perusahaan dengan GCG sebagai variabel pemoderasi pada perusahaan manufaktur yang terdaftar di BEI tahun 2011-2013

Anthony Wijaya dan Nanik Linawati. 2015. pengaruh kinerja keuangan terhadap nilai perusahaan dengan variabel moderator: Corporate Social Responsibility (CSR) dan Good Corporate Governance (GCG). FINESTA Vol. 3, No. 1, 46-51.

Bambang Riyanto, 1995. Dasar-dasar pembelanjaan perusahaan, Edisi keempat, Yogyakarta, Yayasan Penerbit Gajah Mada.

Bastian, Indra dan Suhardjono, 2006. Akuntansi Perbankan, Salemba Empat, Jakarta. 
Ghozali, Imam dan Chariri, Anis. 2007. Teori Akuntansi, Edisi Ketiga, Badan Penerbit Universitas Diponegoro, Semarang.

Hadianto, M.L. Tahun 2013. " Analisis Pengaruh Kinerja Keuangan terhadap Nilai Perusahaan dengan Pengungkapan CSR DAN GCG sebagai Variabel Pemoderasi". Skripsi. Fakultas Ekonomi dan Bisnis. Universitas Diponegoro.

Indrawan, Danu Candra. 2011. Pengaruh corporate social responsibility terhadap kinerja perusahaan. Skripsi Universitas Diponegoro: Semarang.

Januarti dan Apriyanti.2005. Pengaruh Tanggung Jawab Sosial Perusahaan terhadap Kinerja Keuangan. Jurnal MAKSI, Vol. No.2,227-243.

Kasmir. 2008. Analisis Laporan Keuangan, Edisi 1 Cetakan 1, PT Raja Grafindo Persada, Jakarta.

Lanti Triagustina, Edi Sukarmanto, dan Helliana. 2012. Pengaruh ROA dan ROE terhadap nilai perusahaan. Prosiding Akuntansi. ISSN : 2460 - 6561.

Luh Eni Muliani, Gede A.Y, dan Kadek Sinarwati. 2014. Pengaruh Kinerja Keuangan terhadap Nilai Perusahaan dengan Pengungkapan Corporate Social Responsibility dan Good Corporate Governance sebagai Variabel Pemoderasi.

Mardiyanto Handono. 2009. Intisari Manajemen Keuangan. Jakarta : Grasindo.

Mulianti, F. M. 2010. Analisis Faktor-faktor yang Mempengaruhi Kebijakan Hutang dan Pengaruhnya terhadap Nilai Perusahaan (Studi pada Perusahaan Manufaktur yang Terdaftar di Bursa Efek Indonesia (BEI) Perioda Tahun 2004-2007). Tesis, Program Pascasarjana Universitas Diponegoro, Semarang.

Rika Nurlela dan Islahudin. 2008. "Pengaruh Corporate Social Responsibility terhadap Nilai Perusahaan Dengan Prosentase Kepemilikan Manajemen Sebagai Variabel Moderating"(Studi Empiris Pada Perusahann Yang Terdaftar di Bursa Efek Jakarta). Simposium Nasional Akuntansi XI Pontianak 23-24 2008.

Sugiyono, (2008). Metode Penelitian Kunatitatif Kualitatif dan R\&D. Bandung Alfabeta.

Susanto, Priyatna Bagus dan Imam Subekti. 2012. Pengaruh Corporate Social Responsibility dan Good Corporate Governance terhadap Nilai Perusahaan (Pada Perusahaan yang Terdaftar di Bursa Efek Indonesia, Artikel Universitas Brawijaya. 